\title{
Synthesis and photoelectrochemical properties of thin bismuth molybdates film with various crystal phases
}

\author{
Xu Zhao ${ }^{\text {a,b,* }}$, Tongguang $\mathrm{Xu}^{\mathrm{a}}$, Wenqing Yao ${ }^{\mathrm{a}}$, Yongfa Zhu ${ }^{\mathrm{a}, *}$ \\ a Department of Chemistry, Tsinghua University, Beijing, 100084, PR China \\ b State Key Laboratory of Environmental Aquatic Chemistry, Research Center for Eco-Environmental Science, Chinese Academy of Sciences, Beijing, 100085, PR China
}

\section{A R T I C L E I N F O}

\section{Article history:}

Received 23 July 2008

Received in revised form 23 February 2009

Accepted 27 February 2009

Available online 9 March 2009

\section{Keywords:}

Bismuth molybdate film

Photoelectrochemical properties

Visible light

Crystal structure

X-ray diffraction

Optical spectroscopy

Chemical solution deposition

\begin{abstract}
A B S T R A C T
Bismuth molybdate films with various phase structures including $\alpha-\mathrm{Bi}_{2} \mathrm{Mo}_{3} \mathrm{O}_{12}, \beta-\mathrm{Bi}_{2} \mathrm{Mo}_{2} \mathrm{O}_{9}, \gamma-\mathrm{Bi}_{2} \mathrm{MoO}$, and $\gamma^{\prime}-\mathrm{Bi}_{2} \mathrm{MoO}_{6}$ are fabricated on the indium-tin oxide glass substrates from an amorphous heteronuclear complex via the dip-coating method by appropriate adjustment of the reaction conditions. $\alpha-\mathrm{Bi}_{2} \mathrm{Mo}_{3} \mathrm{O}_{12}$, $\beta-\mathrm{Bi}_{2} \mathrm{Mo}_{2} \mathrm{O}_{9}$, and $\gamma-\mathrm{Bi}_{2} \mathrm{MoO}_{6}$ film can be obtained at $400{ }^{\circ} \mathrm{C}, 500{ }^{\circ} \mathrm{C}$, and $500{ }^{\circ} \mathrm{C}$ for $1 \mathrm{~h}$, respectively. At $500{ }^{\circ} \mathrm{C}, \gamma^{\prime}-\mathrm{Bi}_{2} \mathrm{MoO}_{6}$ can be obtained for $4 \mathrm{~h}$. Film formation process is proposed based on the experimental results. Thin $\gamma-\mathrm{Bi}_{2} \mathrm{MoO}_{6}$ films exhibit high photoresponse under visible light irradiation. Incident photon to current conversion efficiency of thin $\gamma-\mathrm{Bi}_{2} \mathrm{MoO}_{6}$ film starts to increase near $450 \mathrm{~nm}$. And, it can reach $4.1 \%$ at $400 \mathrm{~nm}$. The top of the valence band and bottom of the conduction band are roughly estimated to be -0.71 and $1.69 \mathrm{eV}$, respectively. In contrast, $\gamma^{\prime}-\mathrm{Bi}_{2} \mathrm{MoO}_{6}$ generated weak photocurrent; $\alpha-\mathrm{Bi}_{2} \mathrm{Mo}_{3} \mathrm{O}_{12}$ and $\beta-\mathrm{Bi}_{2} \mathrm{Mo}_{2} \mathrm{O}_{9}$ film has no photoresponse under visible light irradiation. The reason for the difference in the visible light response was discussed.
\end{abstract}

(C) 2009 Published by Elsevier B.V.

\section{Introduction}

Photocatalysts that respond to visible light are needed to utilize the main part of the solar spectrum for the production of hydrogen energy by splitting water [1], solar energy cell [2], and other applications [3] Traditional visible-light photocatalysts are either unstable upon illumination with light or have low activity [4]. Recently, some UVactive oxides functioned as visible-light photocatalysts by doping of metal [5], N, C, and S [6]. However, these doped materials, in general, show a small absorption in the visible-light region, leading to low activities [7]. Thus, it is very important to develop more efficient visible-light photocatalysts.

Bismuth molybdates have the general chemical formula of $\mathrm{Bi}_{2} \mathrm{O}_{3}$ $n \mathrm{MoO}_{3}$ where $n=3,2$, or 1 , corresponding to $\alpha, \beta, \gamma$, and $\gamma^{\prime}$ phase, respectively. Such compounds and their mixtures are well known due to their catalytic application in the area of selective oxidation/ oxidative dehydrogenation or ammoxidation of lower olefins [8]. However, each phase exhibits different properties. Recently, photocatalytic activities of $\mathrm{Bi}_{2} \mathrm{WO}_{6}$ have been revealed by Kudo and Hijii [9], Tang et al. [10], and our group [11]. These works revealed tungstates could be performed as good photocatalytic materials under visible light irradiation. Usually, the molybdates have the same crystalline pattern as the tungstates, implying they can also be used as photo-

\footnotetext{
* Corresponding author. Tel.: +861062787601.

E-mail addresses: enzx76@yahoo.com.cn (X. Zhao), zhuyf@mail.tsinghua.edu.cn (Y. Zhu).
}

catalyst. Kudo and his collaborators found that $\mathrm{Bi}_{2} \mathrm{MoO}_{6}$ was able to the photocatalytic $\mathrm{O}_{2}$-evolution under visible light irradiation $[9,12]$. However, its photoelectrochemical (PEC) properties and effect of crystal phases on its PEC properties are still unknown now. Herein, bismuth molybdates films with various crystal phases were fabricated from amorphous heteronuclear complex via dip-coating method. $\gamma-\mathrm{Bi}_{2} \mathrm{MoO}_{6}$ film exhibited high photocurrent response under visible light irradiation. In contrast, $\gamma^{\prime}-\mathrm{Bi}_{2} \mathrm{MoO}_{6}$ films generated weak photocurrent; $\alpha-\mathrm{Bi}_{2} \mathrm{Mo}_{3} \mathrm{O}_{12}$ and $\beta-\mathrm{Bi}_{2} \mathrm{Mo}_{2} \mathrm{O}_{9}$ film nearly had no photoresponse. And, their photoelectrochemical properties were discussed and electron structure of $\gamma-\mathrm{Bi}_{2} \mathrm{MoO}_{6}$ was explored.

\section{Experimental section}

\subsection{Fabrication of bismuth molybdate films}

Indium-tin oxide (ITO) glass was purchased from China Southern Class Co. Ltd., with a thickness of $1.1 \mathrm{~mm}$ and a sheet resistance of $15 \Omega$ /square. The thickness of the ITO layer was $1 \times 10^{-4} \mathrm{~mm}$. All other chemicals are analytical grade reagents and used without further purification. Deionized water was used throughout the experiment. Fabrication of bismuth molybdate films includes preparation of precursor and subsequent deposition and calcinations. Procedures were described below in details. $4.85 \mathrm{~g} \mathrm{Bi}\left(\mathrm{NO}_{3}\right)_{3} 5 \mathrm{H}_{2} \mathrm{O}$ was dissolved in $30 \mathrm{ml}$ water. Following, $10 \mathrm{ml}$ strong ammonia water (28\% by weight) was added slowly and the $\mathrm{pH}$ of the solution was ca. 7. After the precipitates were dispersed completely by 
ultrasonic method, $0.72 \mathrm{~g} \mathrm{MoO}_{3}$ was added. The above suspension was stirred and heated to be $80{ }^{\circ} \mathrm{C}$. Then, $9.83 \mathrm{~g}$ diethylenetriaminepent acetic acid was added. The obtained suspension was stirred and heated at ca. $80{ }^{\circ} \mathrm{C}$ until the mixture became a transparent solution. After being vaporized slowly at $80^{\circ} \mathrm{C}$, a piece of transparent glass-like material was obtained, which was named as precursor. The precursor dissolved in aqueous solution (20\%, by weight) was deposited onto an ITO glass via dip-coating method, and calcined at various temperatures in air for various time.

\subsection{Characterization of bismuth molybdate films}

Morphology of the bismuth molybdates films was characterized by a JSM 6301 electron-scanning microscope (SEM). Raman spectra were conducted on a Renishaw RM1000 spectroscope. The wavelength of the laser light was $514 \mathrm{~nm}$. X-ray diffraction (XRD) was performed on the X-Ray Diffractometer (Japan, Rigaku, D/max-RB) for monochromatizaed $\mathrm{Cu} \mathrm{K} \alpha(\lambda=1.5418 \AA)$ radiation. Thermogravimetry-differential thermal analysis (TG-DTA) was performed on a Du Pont Universal V2.6D thermal analyzer. The atmosphere is air and the heating rate is $10{ }^{\circ} \mathrm{C} / \mathrm{min}$. Fourier transform infrared spectroscopy (FT-IR, Spectrum GX, Perkin-Elmer Company) was used for the assessment of the crystallization of the precursor films. The Auger electron spectroscopy technique was used to determine the thickness of the film. The energy and beam current of the $\mathrm{Ar}$ ion beam were $3.0 \mathrm{keV}$ and $6 \mu \mathrm{A}$, respectively. The beam diameter was $1 \mathrm{~mm}$ and the sputtering rate was approximately $30.0 \mathrm{~nm} / \mathrm{min}$. The film thickness can be determined to be $450 \mathrm{~nm}$.

\subsection{Photoelectrochemical properties of bismuth molybdate films}

The photoelectrochemical experiment was carried out using a PARSTAT 2273 advanced electrochemical system (Princeton Applied Research) with a Lock-In amplifier (Model SR830 DSP, Stanford research systems). For photoelectrochemical measurement, a Cu wire was attached to the bismuth molybdate film with epoxy resin to prevent current leakage. A quartz electrolytic cell was employed, filled with $20 \mathrm{~mL}$ of $0.1 \mathrm{M} \mathrm{KCl}$ solution. A Pt wire and a saturated calomel electrode (SCE) were employed as the counter and reference electrodes, respectively. A $300 \mathrm{~W}$ Xe lamp was used as irradiation source.

\section{Results and discussion}

\subsection{Structure and texture of bismuth molybdates films}

Fig. 1(A) shows the Raman patterns for the precursor film treated at various temperatures for $1 \mathrm{~h}$. The precursor film was amorphous.

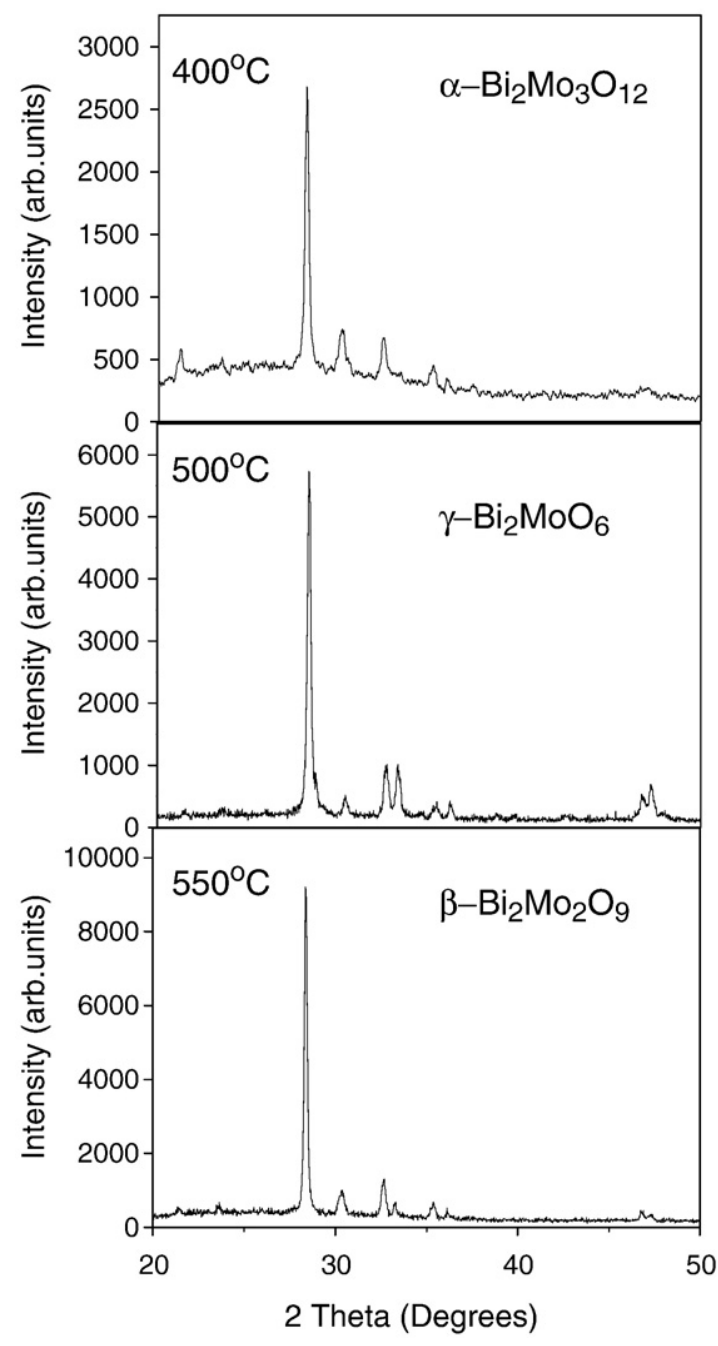

Fig. 2. X-ray diffraction analysis of the precursor film treated at various temperatures for $1 \mathrm{~h}$.

And, the crystalline phase of $\alpha-\mathrm{Bi}_{2} \mathrm{Mo}_{3} \mathrm{O}_{12}$ with the specific band at $899 \mathrm{~cm}^{-1}$ appears at the treated temperature of $400{ }^{\circ} \mathrm{C}$; the crystalline phase of $\gamma-\mathrm{Bi}_{2} \mathrm{MoO}_{6}$ with the specific band at $804 \mathrm{~cm}^{-1}$ appear at $500{ }^{\circ} \mathrm{C}$; the $\beta-\mathrm{Bi}_{2} \mathrm{Mo}_{2} \mathrm{O}_{9}$ with the specific band at $884 \mathrm{~cm}^{-1}$ appears when the temperature is increased to $550{ }^{\circ} \mathrm{C}$. The effect of calcination time on the crystallization of bismuth molybdates were
A

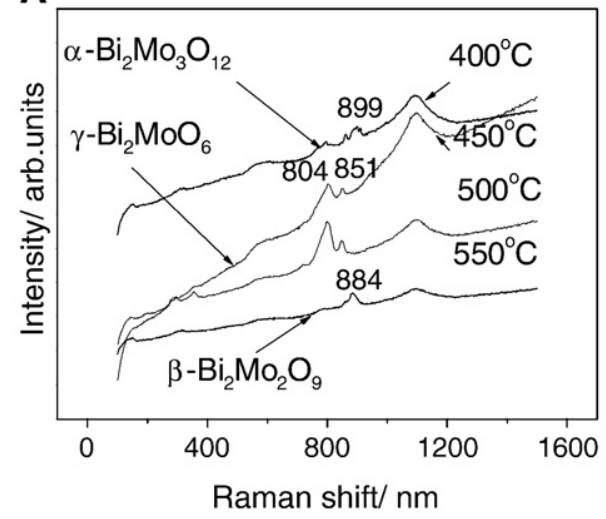

B

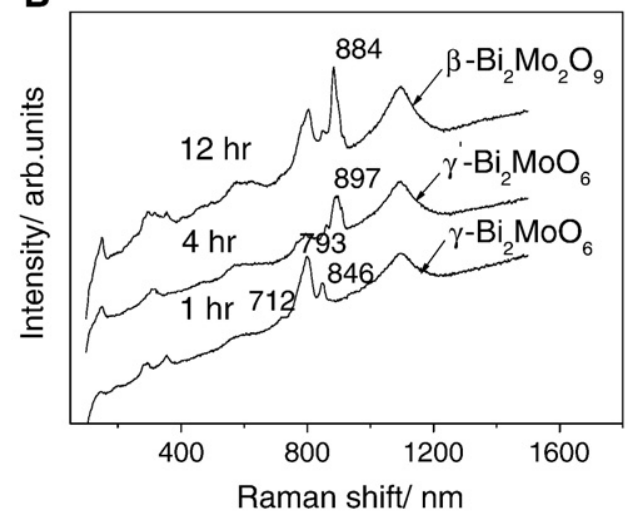

Fig. 1. Raman spectroscopy of the precursor film treated at various conditions. A, different temperatures for $1 \mathrm{~h}$; $\mathrm{B}$, different time at $500{ }^{\circ} \mathrm{C}$. 
investigated at the temperature of $500{ }^{\circ} \mathrm{C}$. For the film sample calcined for $1 \mathrm{~h}$, the strong antisymmetric stretching Mo-O mode observed at $793 \mathrm{~cm}^{-1}$ for the distorted $\mathrm{MoO}_{6}$ octahedra indicate the formation of the $\gamma-\mathrm{Bi}_{2} \mathrm{MoO}_{6}$ phase. In contrast, the Raman spectrum of the film samples treated for $4 \mathrm{~h}$ show a strong antisymmetric stretching Mo-O mode at $890 \mathrm{~cm}^{-1}$, which is characteristic of $\mathrm{MoO}_{4}$ tetrahedra [8]. The above result indicates the formation of $\gamma^{\prime}-\mathrm{Bi}_{2} \mathrm{MoO}_{6}$ phase. When the calcination time is extended to $12 \mathrm{~h}, \beta-\mathrm{Bi}_{2} \mathrm{Mo}_{2} \mathrm{O}_{9}$ appears. Furthermore, the film samples treated at $400{ }^{\circ} \mathrm{C}, 500{ }^{\circ} \mathrm{C}$, and $550{ }^{\circ} \mathrm{C}$ for $1 \mathrm{~h}$ were analyzed by XRD method. As shown in Fig. 2, the film samples treated at $400{ }^{\circ} \mathrm{C}, 500{ }^{\circ} \mathrm{C}$, and $550{ }^{\circ} \mathrm{C}$ can be identified as $\alpha-\mathrm{Bi}_{2} \mathrm{Mo}_{3} \mathrm{O}_{12}$ (JCPDS 21-103), $\gamma-\mathrm{Bi}_{2} \mathrm{MoO}_{6}$ (JCPDS 21-102), and $\beta-\mathrm{Bi}_{2} \mathrm{Mo}_{2} \mathrm{O}_{9}$ (JCPDS 33-209), respectively (Joint Committee on Powder Diffraction Standards, ASTM).

The precursor film was obtained by drying the precursor solution with the initial concentration of $20 \%$ at $90{ }^{\circ} \mathrm{C}$. As shown in Fig. 3, it was uniform and its morphologies change with the annealing temperature. The sample heated at $400{ }^{\circ} \mathrm{C}$ for $1 \mathrm{~h}$ consists of a network of ca. $120 \mathrm{~nm}$ round particles with the crystalline phase of $\alpha-\mathrm{Bi}_{2} \mathrm{Mo}_{3} \mathrm{O}_{12}$. Annealing of a precursor sample at $500{ }^{\circ} \mathrm{C}$ for $1 \mathrm{~h}$ leads to the formation of the $\gamma-\mathrm{Bi}_{2} \mathrm{MoO}_{6}$ film, which is homogeneous and composed of about $70 \mathrm{~nm}$ sized, regular particles and exhibits substantial porosity. At the temperature of $500{ }^{\circ} \mathrm{C}$ for $4 \mathrm{~h}$, the $\gamma^{\prime}-\mathrm{Bi}_{2} \mathrm{MoO}_{6}$ phase appear with large particle size; for $12 \mathrm{~h}$, the $\beta-\mathrm{Bi}_{2} \mathrm{Mo}_{2} \mathrm{O}_{9}$ with the rod-like particles is observed.

In order to explore the formation process of the bismuth molybdate film, the decomposition process of the precursor powders was investigated using TG and DTA curves. As shown in Fig. 4, with

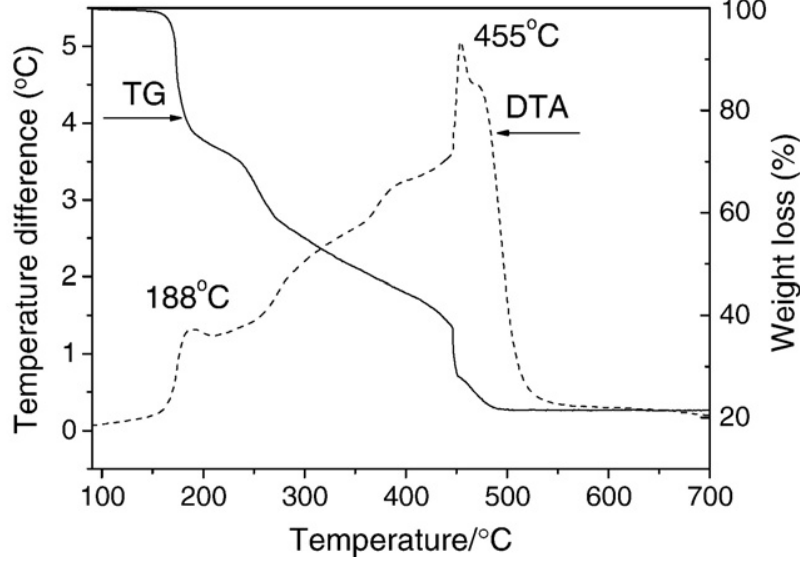

Fig. 4. TG-DTA analysis of the precursor samples,

the increase of temperature, the weight loss occurs in the TG curve up to $500{ }^{\circ} \mathrm{C}$. Thereafter, the weight remains constant, indicating that the decomposition of all organic materials continued in the precursor; their combustion and crystallization of bismuth molybdates have been completed below $500{ }^{\circ} \mathrm{C}$. No significant plateau, corresponding to well-defined intermediate products, appeared in the heating process.
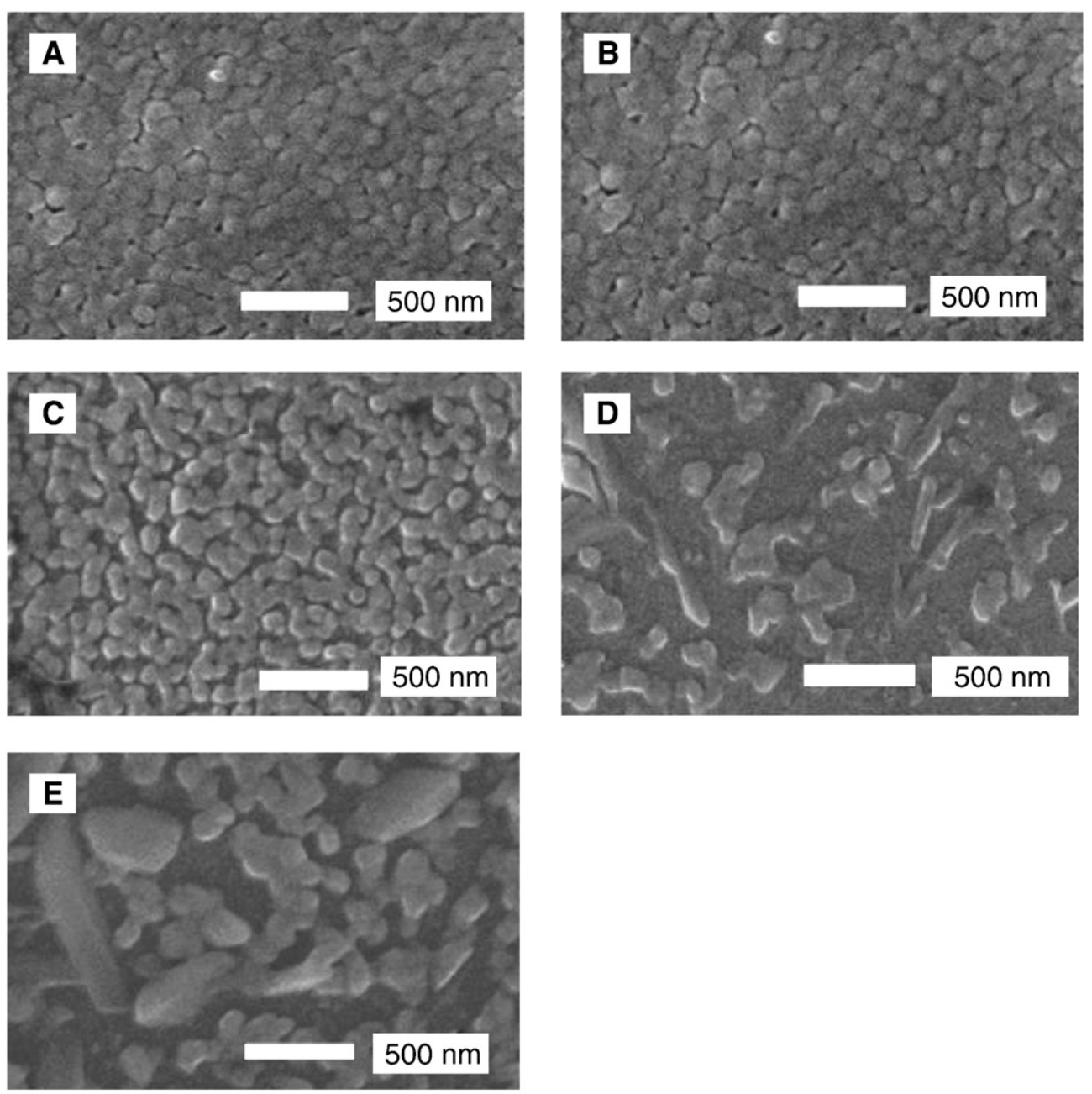

Fig. 3. SEM of the precursor film treated at various conditions (A, Precursor; B, $400{ }^{\circ} \mathrm{C}$ for $1 \mathrm{~h}$; $\mathrm{C}, 500{ }^{\circ} \mathrm{C}$ for $1 \mathrm{~h}$; D, $500{ }^{\circ} \mathrm{C}$ for $4 \mathrm{~h}$; E, $500{ }^{\circ} \mathrm{C}$ for $12 \mathrm{~h}$ ). 


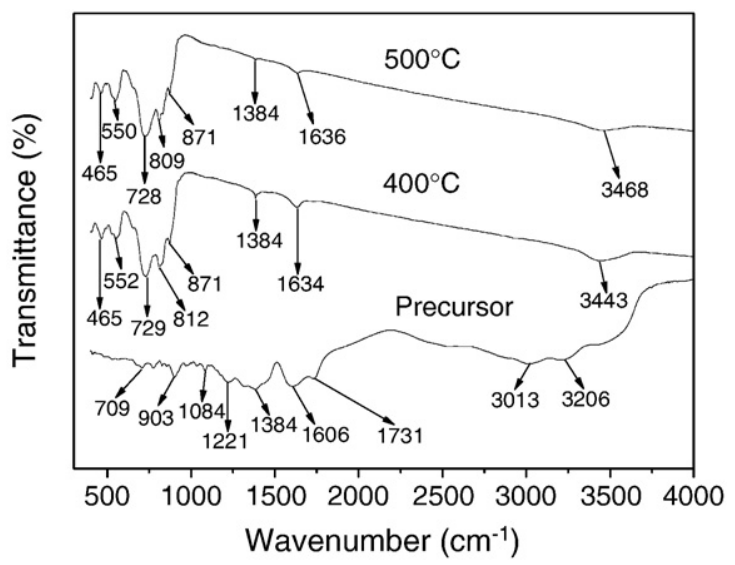

Fig. 5. FT-IR spectra of precursor samples recorded at various temperatures in air.

DTA curve shows two exothermic peaks which could be further classified into two types of physical meaning: (1) left exothermic peaks at $188^{\circ} \mathrm{C}$ correspond to initial decomposition of the precursor and (2) right exothermic peaks at $455^{\circ} \mathrm{C}$ correspond to the formation of the nucleus of the crystal and crystallization of $\gamma-\mathrm{Bi}_{2} \mathrm{MoO}_{6}$. Below $455{ }^{\circ} \mathrm{C}$, the resulting powders were dark brown, hard and porous, denoting an amorphous phase. It is attributed to contain a lot of carbons and ignitable organics. At the temperature of $455{ }^{\circ} \mathrm{C}$, crystal nuclear begins to form, and the primary crystallizing process has been completed accompanying the combustion of the residual carbons and ignitable organics.

Furthermore, the precursor powder sample and precursor samples treated at 450 and $500{ }^{\circ} \mathrm{C}$ for $1 \mathrm{~h}$ were analyzed by FT-IR. The results are presented in Fig. 5. The bands of FT-IR spectra of the precursor film at $3206,3013,1731,1606,1221,1084,903$, and $709 \mathrm{~cm}^{-1}$ originated from the $\mathrm{NH}_{2}, \mathrm{C}-\mathrm{N}, \mathrm{C}=\mathrm{O}, \mathrm{C}-\mathrm{O}$, and $\mathrm{C}-\mathrm{H}$ bands. Above $400{ }^{\circ} \mathrm{C}$, these bands almost completely disappear. For the sample treated at $400{ }^{\circ} \mathrm{C}$, the bands of 729,812 , and $871 \mathrm{~cm}^{-1}$ are assigned to Mo-O stretching bands; the bands of 465 and $552 \mathrm{~cm}^{-1}$ are assigned to the stretching and deformation modes involving $\mathrm{Bi}-\mathrm{O}$ modes. These bands can be ascribed to vibration modes of bismuth molybdates according to data in the literature [13]. No noticeable change is observed in the samples treated at $400{ }^{\circ} \mathrm{C}$ and $500{ }^{\circ} \mathrm{C}$. In deed, IR spectra reported in the literature for $\alpha, \beta$, and $\gamma$ phase display strong absorptions in the same frequency range [14].

\subsection{Photoelectrochemical properties of the bismuth molybdates films}

Fig. 6 shows the current-voltage plots for the precursor film annealed at various temperatures under the condition of dark or

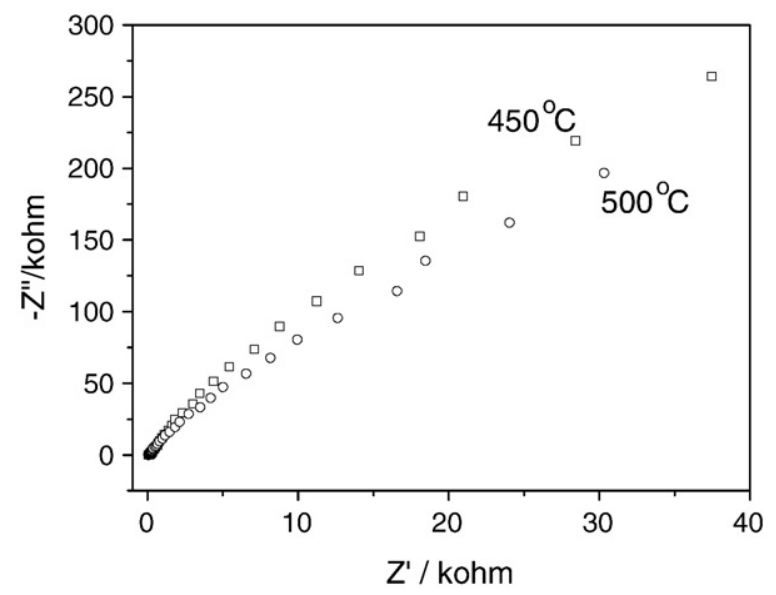

Fig. 7. Electrochemical impedance spectra plane display of the $\gamma-\mathrm{Bi}_{2} \mathrm{MoO}_{6}$ film samples treated at $450{ }^{\circ} \mathrm{C}$ and $500{ }^{\circ} \mathrm{C}$.

visible light irradiation, respectively. There was a significant photocurrent generation for the film samples treated at 450 and $500{ }^{\circ} \mathrm{C}$ for $1 \mathrm{~h}$ (Fig. 6(A)). However, no photocurrent generation is observed for the film samples treated at 400 and $550{ }^{\circ} \mathrm{C}$. From Fig. 6(B), it can be seen that the photocurrent density for the film samples treated at $500{ }^{\circ} \mathrm{C}$ for $1 \mathrm{~h}$ was larger than that of the film samples treated for $4 \mathrm{~h}$. Moreover, the photocurrent is nearly not observed for the film samples treated for $12 \mathrm{~h}$.

It is clear that the $\gamma$ phase for the $\mathrm{Bi}_{2} \mathrm{MoO}_{6}$ film has higher photocurrent response than the $\gamma^{\prime}$ phase for the $\mathrm{Bi}_{2} \mathrm{MoO}_{6}$ film under visible light irradiation. No photocurrent is generated from the $\alpha$ $\mathrm{Bi}_{2} \mathrm{Mo}_{3} \mathrm{O}_{12}$ and $\beta-\mathrm{Bi}_{2} \mathrm{Mo}_{2} \mathrm{O}_{9}$ film. $\gamma-\mathrm{Bi}_{2} \mathrm{MoO}_{6}$ consists of $\mathrm{Mo}-\mathrm{O}, \mathrm{O}$, and $\mathrm{Bi}-\mathrm{O}$ layers. Mo and oxygen exists as distorted octahedral structure. $\gamma^{\prime}-\mathrm{Bi}_{2} \mathrm{MoO}_{6}$ has twin Mo tetrahedral structure and Mo and Bi ions lies on the same plane [15]. This difference probably affects the charge separation and delocalization of photogenerated electrons and holes. The $\alpha$ - and $\beta$-phases differ substantially in structure from the $\gamma$ phase. The structures of the $\alpha$ - and $\beta$-phases can be considered as defective fluorite structures, whereas the $\gamma$-phase is an Aurivilliustype structure [16]. Shimodaira et al. [17] revealed that only these materials containing $\mathrm{MoO}_{6}$ octahedra in the structure showed the photocatalytic activity whereas those containing $\mathrm{MoO}_{4}$ tetrahedra showed negligible photocatalytic activities among the bismuth molybdates. Our results are consistent with it. It is considered that $\mathrm{Bi}_{2} \mathrm{MoO}_{6}$ showed higher activity than $\mathrm{Bi}_{2} \mathrm{Mo}_{3} \mathrm{O}_{12}$ is the crystal structure. $\mathrm{Bi}_{2} \mathrm{MoO}_{6}$ possessed perovskite-like slabs consisting of $\mathrm{MoO}_{6}$ octahedra of which the structure is often advantageous for photocatalysts because excitation energy can easily migrate in the
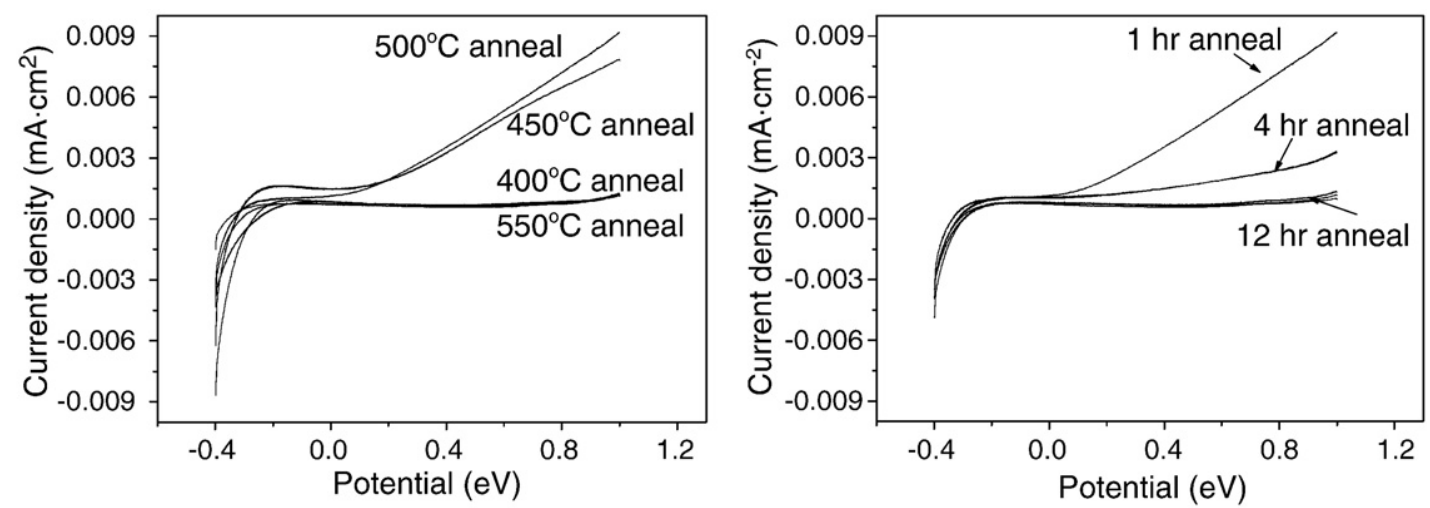

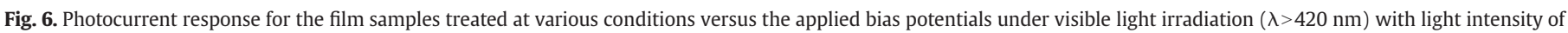
$150 \mathrm{~mW} / \mathrm{cm}^{2}$. A, different temperatures for $1 \mathrm{~h}$; B, different time at $500{ }^{\circ} \mathrm{C}$. 
structure. With respect to the $\gamma-\mathrm{Bi}_{2} \mathrm{MoO}_{6}$ film samples, higher photocurrent for the film sample treated at $500{ }^{\circ} \mathrm{C}$ than that treated at $450{ }^{\circ} \mathrm{C}$ can be due to the relatively large size of the particles and the nature of the interparticle contacts. In such a situation, the electrical contact at the interface can be improved. As a result of the improved electrical contact at the $\gamma-\mathrm{Bi}_{2} \mathrm{MoO}_{6}$ interface and the blocking of the $\gamma$ $\mathrm{Bi}_{2} \mathrm{MoO}_{6}$ surface states, the overall charge-transfer resistance of the film treated at $500{ }^{\circ} \mathrm{C}$ appears to be smaller compared with that of the film samples treated at $450{ }^{\circ} \mathrm{C}$, as shown in Fig. 7 .

Incident photon to current conversion efficiency (IPCE) defined as the number of electrons collected per incident photon, was evaluated from short circuit photocurrent $\left(I_{\mathrm{sc}}\right)$ measurements at different wavelengths $(\lambda)$ and using the following expression (Eq. (1)):

$\mathrm{IPCE} \%=\left[1240 \times I_{\mathrm{sc}}\left(\mathrm{mA} / \mathrm{cm}^{2}\right)\right] /\left[\lambda(\mathrm{nm}) \times I_{\mathrm{inc}}\left(\mathrm{mW} / \mathrm{cm}^{2}\right)\right] \times 100$

Where $I_{\text {inc }}$ is the incident light intensity. As shown in Fig. 8, the IPCE value of $\gamma-\mathrm{Bi}_{2} \mathrm{MoO}_{6}$ film is higher than that of the $\gamma^{\prime}-\mathrm{Bi}_{2} \mathrm{MoO}_{6}$ film. In contrast, no IPCE response is observed for the $\alpha-\mathrm{Bi}_{2} \mathrm{Mo}_{3} \mathrm{O}_{12}$ and $\beta-\mathrm{Bi}_{2} \mathrm{Mo}_{2} \mathrm{O}_{9}$ film. For the $\gamma-\mathrm{Bi}_{2} \mathrm{MoO}_{6}$ film, IPCE starts to increase near $450 \mathrm{~nm}$. It can reach $4.1 \%$ at $400 \mathrm{~nm}$. The above results are consistent with the photocurrent response as shown in Fig. 6.

Fig. 9(A) showed a typical diffuse reflection spectrum of $\gamma-\mathrm{Bi}_{2} \mathrm{MoO}_{6}$ powder treated at $500{ }^{\circ} \mathrm{C}$ for $1 \mathrm{~h}$. The steep shape of the spectra indicated that the visible light absorption was not due to the transition from the impurity level but was due to the band-gap transition [18]. The band gap energy, $E_{\mathrm{g}}$ of the $\gamma-\mathrm{Bi}_{2} \mathrm{MoO}_{6}$ powder is determined using the following equation [19], $a h v=A\left(h v-E_{\mathrm{g}}\right)^{1 / 2}$, where $a, v, E_{\mathrm{g}}$, and $A$ are absorption coefficient, light frequency, band gap, and a constant, respectively. The band gap energy of the $\gamma-\mathrm{Bi}_{2} \mathrm{MoO}_{6}$ film was estimated to be $2.40 \mathrm{eV}$. For the $\gamma-\mathrm{Bi}_{2} \mathrm{MoO}_{6}$ phase, the band starts at $480 \mathrm{~nm}$, which is originated by the $\mathrm{O}^{2-} \rightarrow \mathrm{Mo}^{6+}$ charge transfer process for octahedral $\left[\mathrm{MoO}_{6}\right]$ species. In contrast, the corresponding band for $\left[\mathrm{MoO}_{4}\right]$ species existing in $\alpha-\mathrm{Bi}_{2} \mathrm{Mo}_{3} \mathrm{O}_{12}$, is expected at $440 \mathrm{~nm}$; And, the $\beta-\mathrm{Bi}_{2} \mathrm{Mo}_{3} \mathrm{O}_{12}$ has two absorption bands at 526 (very weak) and $580 \mathrm{~nm}$, together with the beginning of a charge transfer band at $480 \mathrm{~nm}$; this band can be ascribed to $\left[\mathrm{MoO}_{6}\right]$ species, while the bands at 526 and $580 \mathrm{~nm}$ can be ascribed to octahedral $\left[\mathrm{MoO}_{6}\right]$ species [20]. It is well known that the flatband potential $\left(E_{\mathrm{fb}}\right)$ of a semiconductor can be obtained from the intercept of Mott-Schottky plot [21]. Fig. 9(B) shows the Mott-Schottky plot for the $\gamma-\mathrm{Bi}_{2} \mathrm{MoO}_{6}$ film in the electrolyte solution of $0.1 \mathrm{M} \mathrm{KCl}$ in the dark. Straight line is observed; a single

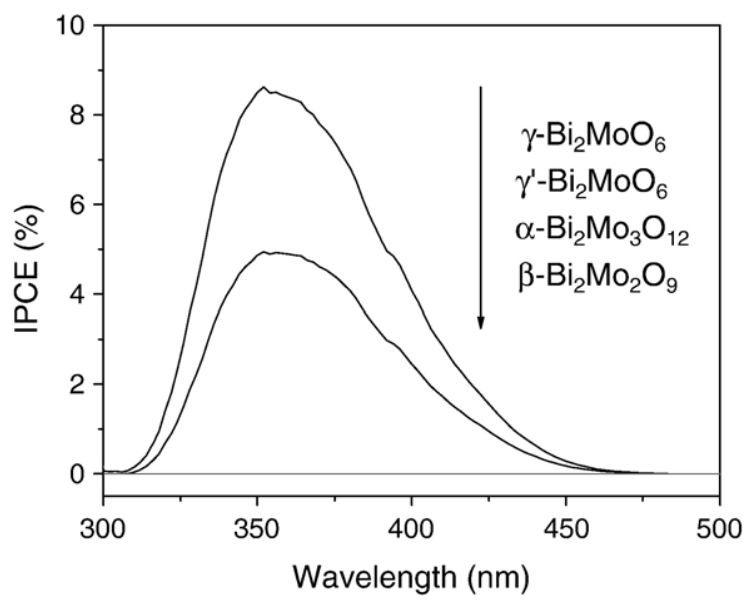

Fig. 8. IPCE vs. $\lambda$ for the $\alpha-\mathrm{Bi}_{2} \mathrm{Mo}_{3} \mathrm{O}_{12}, \beta-\mathrm{Bi}_{2} \mathrm{Mo}_{2} \mathrm{O}_{9}, \gamma-\mathrm{Bi}_{2} \mathrm{MoO}_{6}$, and $\gamma^{\prime}-\mathrm{Bi}_{2} \mathrm{MoO}_{6}$ film electrode in $0.1 \mathrm{M} \mathrm{KCl}$ solution at various potentials under monochromatic light irradiation.
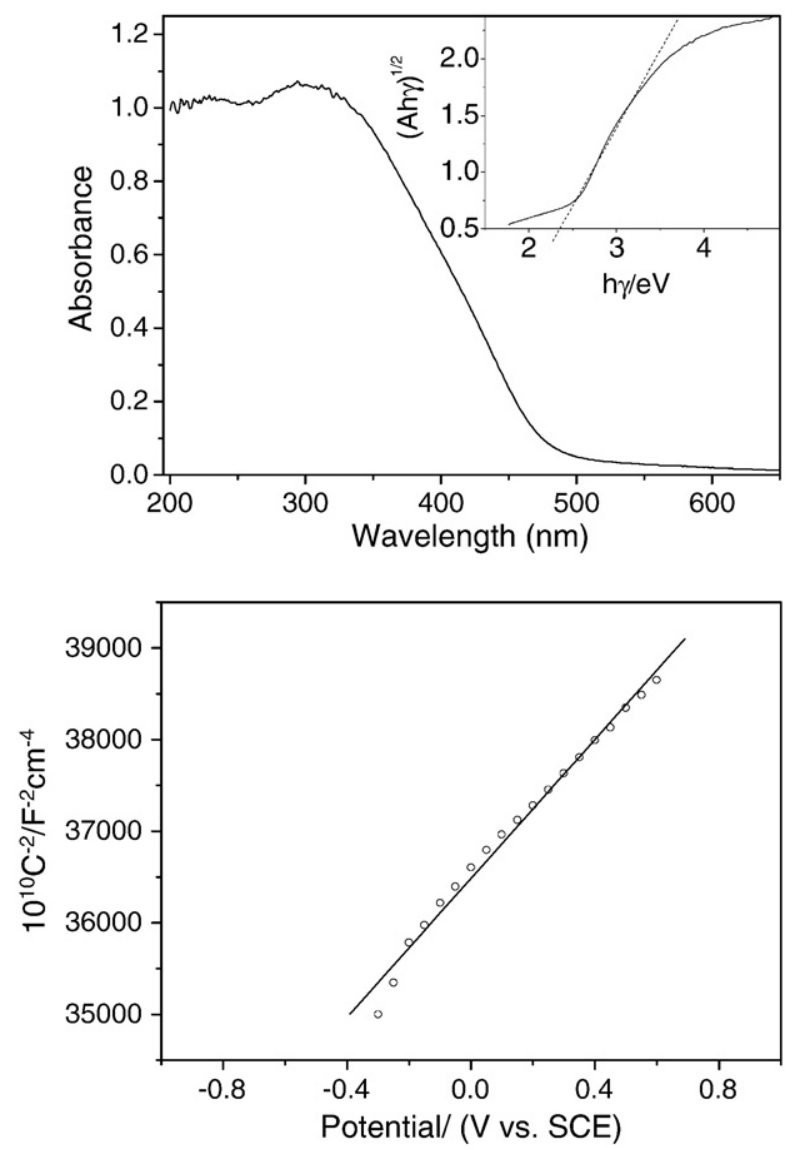

Fig. 9. UV-Vis diffuse reflectance spectroscopy of the $\gamma-\mathrm{Bi}_{2} \mathrm{MoO}_{6}$ powder and MottSchottky plot of the $\gamma-\mathrm{Bi}_{2} \mathrm{MoO}_{6}$ film in $0.1 \mathrm{M} \mathrm{KCl}$ solution (the frequency of the ac signal was $1 \mathrm{kHz}$ ).

intercept is obtained at $-0.51 \mathrm{~V} / \mathrm{SCE}$, giving a flatband potential of $0.51 \mathrm{~V} / \mathrm{SCE}$ approximately.

\section{Conclusion}

Thin bismuth molybdate films with various crystal phase structures can be fabricated from an amorphous heteronuclear complex via the dip-coating method by the adjustment of reaction time and temperature. Under visible light irradiation, the photocurrent generated from $\gamma-\mathrm{Bi}_{2} \mathrm{MoO}_{6}$ is higher than that of $\gamma^{\prime}-\mathrm{Bi}_{2} \mathrm{MoO}_{6}$. Distortion of $\mathrm{Bi}-\mathrm{O}$ band was suggested to contribute to the different photocurrent response. No photocurrent was generated from $\alpha-\mathrm{Bi}_{2} \mathrm{Mo}_{3} \mathrm{O}_{12}$ and $\beta-\mathrm{Bi}_{2} \mathrm{Mo}_{2} \mathrm{O}_{9}$ film. For the $\gamma-\mathrm{Bi}_{2} \mathrm{MoO}_{6}$ film, IPCE of $4.1 \%$ can be obtained at $400 \mathrm{~nm}$. Many parts of the fabrication including variation of surface texture and film thickness have still to be optimized and we expect that the efficiency of the $\gamma-\mathrm{Bi}_{2} \mathrm{MoO}_{6}$ film can be improved.

\section{Acknowledgement}

This work was supported by Chinese National Science Foundation (20837001, 20673065, 50778172).

\section{References}

[1] A. Fujishima, K. Honda, Nature 238 (1972) 37.

[2] M. Gratzel, Nature 414 (2001) 338.

[3] M.R. Hoffman, S.T. Martin, W. Choi, D.W. Bahnemann, Chem. Rev. 95 (1995) 69.

[4] D.W. Hwang, J. Kim, T.J. Park, J.S. Lee, Catal. Lett. 80 (2002) 53.

[5] Z.G. Zou, J.H. Ye, K. Sayama, H. Arakawa, Nature 414 (2001) 625.

[6] A. Ishikawa, T. Takata, J.N. Kondo, M. Hara, H. Kobayashi, K. Domen, J. Am. Chem. Soc. 124 (2002) 547.

[7] D.W. Hwang, H.G. Kim, J.S. Lee, J. Kim, W. Li, S.H. Oh, J. Phys. Chem. B. 109 (2005) 2093. 
[8] A.M. Beale, G. Sankar, Chem. Mater. 15 (2003) 146.

[9] A. Kudo, S. Hijii, Chem. Lett. (1999) 1103.

[10] J.W. Tang, Z.G. Zou, J.H. Ye, Catal. Lett. 92 (2004) 53.

[11] C. Zhang, Y.F. Zhu, Chem. Mater. 17 (2005) 3537.

[12] J.Q. Yu, A. Kudo, Chem. Lett. 34 (2005) 1528

[13] F. Trifiro, H. Hoser, R.D. Scarle, J. Catal. 25 (1972) 12.

[14] I. Matsuura, R. Schut, K. Hirakawa, J. Catal. 63 (1980) 152.

[15] A.F. Van den Elzen, G.D. Riek, Acta Cryst. B. 29 (1973) 2433.
[16] L.M. Reilly, G. Sanar, C.R.A. Catlow, J. Solid. State. Chem. 148 (1999) 178.

[17] Y. Shimodaira, H. Kato, H. Kobayashi, A. Kudo, J. Phys. Chem. B. 110 (2006) 17790.

[18] A. Kudo, I. Tsuji, H. Kato, Chem. Commun. (2002) 1958.

19] M.A. Butler, Appl. Phys. 48 (1977) 1914.

[20] G.W. Smith, J.A. Ibers, Acta Crystallogr. 19 (1965) 269.

[21] S.U.M. Khan, J. Akikusa, J. Phys. Chem. B. 103 (1999) 7184. 